University of Nebraska - Lincoln

DigitalCommons@University of Nebraska - Lincoln

1988

\title{
Cupular Structure in Paleotropical Castanopsis (Fagaceae)
}

Robert B. Kaul

University of Nebraska-Lincoln

Follow this and additional works at: https://digitalcommons.unl.edu/bioscifacpub

Part of the Biology Commons, and the Botany Commons

Kaul, Robert B., "Cupular Structure in Paleotropical Castanopsis (Fagaceae)" (1988). Faculty Publications in the Biological Sciences. 853.

https://digitalcommons.unl.edu/bioscifacpub/853

This Article is brought to you for free and open access by the Papers in the Biological Sciences at DigitalCommons@University of Nebraska - Lincoln. It has been accepted for inclusion in Faculty Publications in the Biological Sciences by an authorized administrator of DigitalCommons@University of Nebraska - Lincoln. 


\title{
CUPULAR STRUCTURE IN Robert B. Kaul ${ }^{2}$ PALEOTROPICAL CASTANOPSIS (FAGACEAE)
}

\begin{abstract}
The structure and some developmental aspects of the cupules of 22 species of paleotropical Castanopsis are discussed and illustrated. Some species have cupules massively invested with strong, sharp spines, but others are less spiny, and some are nearly smooth. Most cupular armament results from spines produced axillary to the valvular scales and basally adnate to them. Columns of scales straddling the sutures between the cupular valves do not become spines, but the numerous scales elsewhere on the valves become somewhat spiny with age. Dehiscence in the spiny-valved species is mostly along the sutures. The smooth cupules of some species have scales in their early stages, but cupular expansion separates and tears them; such species are often indehiscent or only irregularly dehiscent and usually show nearly complete adnation of the cupule to the nut.
\end{abstract}

Castanopsis is the third largest genus in the Fagaceae, after Quercus and Lithocarpus in their broad sense. Most of the approximately 120 species recognized by Camus (1929) and Barnett (1944) are paleotropical, but a few occur as far north as northeastern China, Korea, and Japan, and some ascend the Himalayas. For Malesia (the Malay Peninsula and all the islands from Sumatra to New Guinea and the Philippines) Soepadmo (1968, 1972) recognized 34 species and mapped species density. In Malesia, Borneo has the most species (21) and the most endemics (10); Sumatra and Java have 11 and 4 species, respectively, none endemic; and the Philippines have 4 , including one endemic. Only two-C. buruana and C. acuminatissimaoccur east of Wallace's Line between Bali and Lombok. Barnett (1942) found only one endemic species among the 16 she recognized for Thailand. About 25 are known from China, mostly from the southern provinces. The eight or nine mostly endemic Taiwanese species are taxonomically well studied (Li, 1963; Lin \& Liu, 1965; Liao, 1971; Liu \& Liao, 1976). One species (C. cuspidata), represented by two varieties, occurs in Japan (Ohwi, 1965). The one or two species outside Asia and nearby islands occur in western North America and are sometimes given their own genus, Chrysolepis, based largely upon cupular structure; palynologically they are indistinguishable from Cas- tanopsis (Erdtman, 1943; Crepet \& Daghlian, 1980), and foliar distinctions are weak (Jones, 1986). Lithocarpus, closely related and with perhaps 300 species, has a remarkably similar geographic distribution, including a single species in western North America.

Castanopsis in Malesia is characteristic of forests without strongly seasonal climates, but in Java and Thailand some species occur in seasonal climates (Hjelmqvist, 1968; Soepadmo, 1972). Twelve of the 34. Malesian species are restricted to lowland forests, and the others are in lowland and montane forests. Barnett (1942) and Hjelmqvist (1968) noted that the species of Thailand are found mostly in the uplands. Most paleotropical species of Castanopsis grow in mixed forests that often include Lithocarpus and Quercus, but C. acuminatissima forms nearly pure stands in New Guinea (Soepadmo, 1972; Whitmore, 1975; Paijmans, 1976). The genus is prominent in subtropical forests of China (Wang, 1961). The northeastern Asiatic and western North American species are sometimes abundant in the forests and are, of course, subjected to more seasonal climates than are most paleotropical species.

Pollination by small insects is suggested by their abundance around the rather strong-smelling, conspicuous staminate flowers, but some pollen might be wind-transported. It is not clear how the incon-

\footnotetext{
${ }^{1}$ Research supported by National Science Foundation grants DEB 8206937 and BSR 8508046. Grateful acknowledgment is made to E. C. and L. B. Abbe, A. L. and M. P. Bogle, and all those persons and institutions cited earlier (Kaul \& Abbe, 1984) for their contributions in the field and laboratory.

${ }^{2}$ School of Biological Sciences, University of Nebraska, Lincoln, Nebraska 68588-0118, U.S.A.
}

ANN. Missouri Bot. Gard. 75: 1480-1498. 1988. 
spicuous, presumably odorless pistillate flowers attract insects; perhaps they are pollinated only incidentally to insect movements among the far more numerous staminate flowers around them.

The published infrageneric classifications of Castanopsis are based mostly upon fruit characters, as is the case for other fagaceous genera. Camus (1929) recognized three sections in Castanopsis: Eucastanopsis (cupule spiny, dehiscent or indehiscent, the nuts not fused to it); Callaeocarpus (cupule with or without spines, the nuts fused to it for most of their length); and Pseudopasania (cupule thin, dehiscent, containing a single free nut). The last group includes $C$. acuminatissima.

Barnett (1944) saw the genus as comprising 11 groups in Asia and nearby islands, but she did not give them formal taxonomic rank. She defined them by degree of adnation of the cupule to the nuts, ornamentation of the cupule, size of the scar of the nuts, size of the fruits, and foliar characters. She included the small "fissa-group" in Castanopsis, noting that it forms a connecting link to Lithocarpus; Forman (1966a, b) also aligned the fissa-group with Castanopsis, noting its strong alliance with C. acuminatissima, but Camus (1929) placed those species in Lithocarpus subg. Pseudocastanopsis. Thus these authors recognized the close affinity of Castanopsis to Lithocarpus, and Barnett (1940) suggested that recognition of two genera is perhaps more artificial than natural. Jones (1986) supported the placement of the fissa-group in Castanopsis, based upon his detailed study of foliar characteristics in the family.

Camus (1929) suggested that Castanopsis is closer to Lithocarpus than Lithocarpus is to Quercus, and recent foliar and palynological evidence supports her interpretation (Jones, 1986; Zavada \& Dilcher, 1986). (Lithocarpus and Quercüs are usually interpreted as distinct from each other, but exhibit many parallel traits.) The affinity of Castanopsis to Castanea is undoubtedly close.

Hjelmqvist (1948, 1968) and Forman (1966a, b) saw Castanopsis and Lithocarpus as distinct, noting the differences between the dichasium-cupule, which encloses all the flowers of a cymule in Castanopsis, and the flower-cupule enclosing individual flowers of a cymule in Lithocarpus. They interpreted the dichasium-cupule as a product of phylogenetic fusion of flower-cupules, and the dichasium-cupule of the one-flowered cymules of the fissa-group and other species thus as indistinguishable from a flower-cupule. The valveless cupules of Lithocarpus and Quercus are apparently morphologically identical also, but Forman (1966a) suggested that they are convergently derived, the cupule of Lithocarpus being a true flower-cupule and that of Quercus being a one-flowered dichasium-cupule whose lateral flowers have disappeared. However, there is no direct evidence for that in Quercus; rather, it was based upon comparative study of other genera, especially Trigonobalanus daichangensis. Some species of Lithocarpus show partial to nearly complete fusion of flower-cupules in the cymules, resulting in partial dichasium-cupules (examples illustrated in Kaul, 1987), which Forman (1966a) interpreted as phylogenetically parallel to the dichasium-cupules of Castanopsis.

In Castanopsis the cupular primordia are rather well developed by anthesis (but less so than in Castanea). The mature cupule encloses the one to seven nuts and often has distinct vertical sutures that define the cupular "valves," at the edges of which dehiscence often occurs (such features are not found in Lithocarpus and Quercus). However, variations in these and other characteristics occur within and between species.

The origin and structure of the fagaceous cupule have had various interpretations; Abbe (1974), Okamoto (1982), and Fey \& Endress (1983) reviewed the literature, in which it is implied that the cupule has arisen but once. Most workers interpret it as derived from pre-existing structures, not as a structure de novo. Whatever the origin of the cupule, it now has some qualities and functions unlike those of its ancestral parts. Fey \& Endress (1983) found that ontogenetic observations in Castanea, Fagus, and Quercus revealed more orderly arrangement of cupular appendages than is evident at maturity. This is true for Castanopsis too, in which the mature cupule is often massively invested with rigid spines and other structures that obscure positional relationships. Castanopsis is largely unstudied developmentally, but floral development in C. cuspidata var. sieboldii of northeastern Asia and Japan has been shown in detail (Okamoto, 1983). Castanea has been the subject of several developmental studies, most recently by Fey \& Endress (1983).

Many species of Castanopsis have spiny cupules, but in others spines are barely evident or absent, and the cupule is then smooth and figlike. Forman (1966a) interpreted the spines as emergences, not foliar homologues. Barnett (1940) noted that they do not appear to be the first cupular appendages to form, but develop later, often in the axils of the "scales." Fey \& Endress (1983) interpreted spines of Castanea as axillary branch systems.

The patterns of distribution and elaboration of 


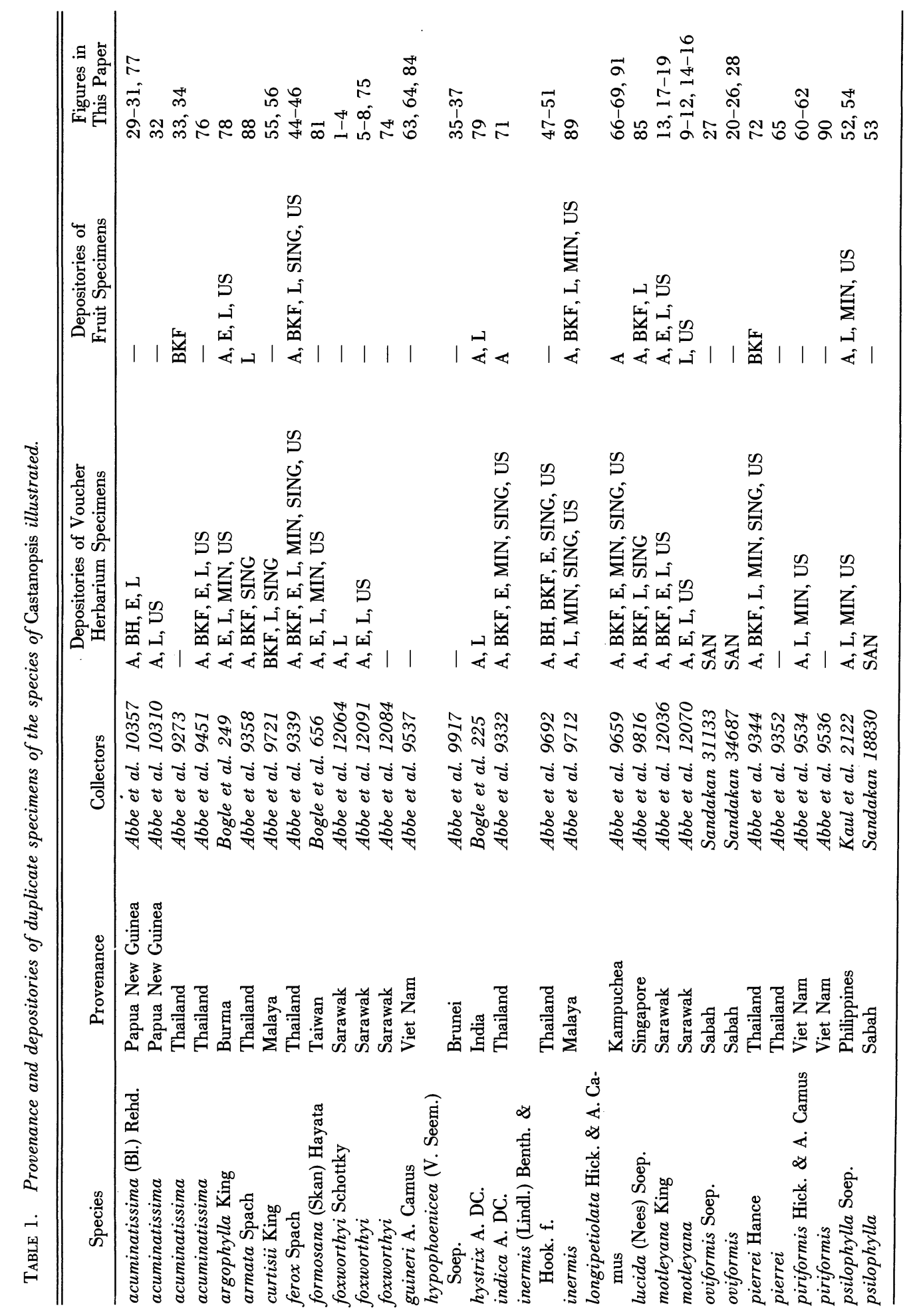


cupular scales, spines, and sutures vary among the species, and the functional and phylogenetic significance of the various patterns is not known. Forman (1966a) interpreted as primitive in Cas tanopsis the three- or more-flowered cymule; the four-valved cupule dehiscing between the valves; the spines branched, well developed, and in definite rows; and the cupule not adnate to the nut(s). Those characteristics are most common in paleotropical species. He saw derived conditions in the oneflowered cymule, the two-valved cupules, irregular dehiscence not along valve sutures, the spines absent or reduced and not in obvious rows, and the cupule fused to the nut(s). Those attributes occur in paleotropical and palearctic species. He also interpreted the American species as primitive because the valves are free, and some occur between the flowers of a cymule-characteristics used to distinguish Chrysolepis from Castanopsis. Hjelmqvist (1948) reported remnants of walls between the nuts in the cupules of Castanopsis hullettii and $C$. fabri.

Hjelmqvist (1948) interpreted one-flowered, three-parted cupules as originating by the union of three flower cupules, one middle and two lateral cupules. He suggested that in four-parted cupules the middle cupule is reduced and the remaining common (dichasium) cupule is four-parted, the parts corresponding to two bipartite, lateral cupules. Dehiscence then occurs along the longitudinal fissures through the middle of the part-cupules and at the border between the two anterior cupules.

\section{Materials AND Methods}

My colleagues and I collected Castanopsis and other Fagaceae from India to New Guinea and Japan, gathering developmental reproductive material wherever possible. We preserved specimens originally in various liquid fixatives and later transferred them to glycerine-alcohol for permanent storage. For three species from the lowlands of Borneo (C. foxworthyi, C. motleyana, and C. oviformis) we took samples at intervals from marked trees through most of a year. The species reported upon in this paper are listed in Table 1.

The study of reproductive structures of Castanopsis presents unusual technical difficulties. Sectioning and clearing, even of young flowers, do not produce photogenic results because of the hard spines and cupules, the numerous hairs, and the heavy sclerification of tissues. Specimens were examined with light and scanning electron microscopy (often following removal of obscuring structures), drawings were produced with the camera lucida, and photographs were taken with incident light. 
The dense vestiture obscures many details, and so the line drawings are shown without hairs.

Various sets of herbarium voucher specimens were distributed to $\mathrm{A}, \mathrm{BH}, \mathrm{BKF}, \mathrm{E}, \mathrm{L}, \mathrm{MIN}, \mathrm{SAN}$, SAR, SING, and US (Table 1). The fruits illustrated here are in my research collection, and not all the distributed vouchers have fruits at all stages illustrated in this paper.

Nomenclature for paleotropical species follows Soepadmo (1972), who identified most of my paleotropical specimens. I considered the fissa-group with Lithocarpus (Kaul, 1987), following Camus's system, but a good case can be made for including it in Castanopsis if the two genera are recognized as distinct (Forman, 1966a, b).

\section{OBservations}

\section{PISTILLATE CYMULES}

The pistillate cymules (often called dichasia) are borne on androgynous, pistillate, or androgynecandrous spikes (Kaul \& Abbe, 1984; Kaul, 1986). They contain one, two, three, or sometimes more flowers (Figs. 1, 4-6, 10, 11, 13, 14, 17, 20, 25, 29-31, 38-40, 47, 52, 55, 56, 66, 70-77). The number of flowers per cymule is more stable in some species than others. Often there are fewer flowers. in more distal cymules, and in some species that ordinarily bear one-flowered cymules, occasional two-flowered cymules appear. When three or more flowers occur in a cymule, the central flower often develops slightly earlier than the others (Fig. 10).

Each cymule is subtended by a primary bract (shown in black in Figs. 1, 5, 14, 20, 25, 29, 30, $38,47,52,55,56,60$, and evident in Figs. 70, $72,76)$ and secondary, tertiary, and sometimes quaternary or even higher-order bracteoles (Figs. 72-77). Distinctions between these bracteoles and those of the cupule (hereinafter called scales) are not always obvious. The pattern of bracteolation in Castanopsis is closely similar to that shown for Lithocarpus (Kaul, 1987 and in press).

The apparent pedicel of a flower in anthesis (Figs. 1-3, 12, 21, 22) is actually the very undeveloped inferior ovary, and the flower is thus sessile in the cupule.

All species examined at anthesis have prominent staminodia (e.g., Figs. 30, 31, 77), which are sometimes basally adnate to the perianth (Fig. 12).

\section{FRUITS}

The fagaceous nut develops from an inferior ovary, and the cupule is an accessory part. If all nuts of a cymule are abortive (probably due to lack of pollination or fertilization, or to competition for resources from other fruits on the rachis), cupular growth stops at about the stages shown in Figures $5,7,14,18,25,31,33,35,36,39,40,48$, and 53. But if one or more nuts mature, the cupule matures. The mature cupule is not fused to the nuts in some species; it is partially or completely fused in others. Some species have notably scaly and/or spiny cupules, others have rudimentary spines, and some are spineless or scaleless.

A cupule surrounds all flowers of a cymule, and there are no well-developed valves (segments of cupules) between the flowers except in the American species. Rudimentary interfloral valves were reported by Hjelmqvist (1948) in C. hullettii and C. fabri, but I have not studied those species and have not seen such valves in others.

Spiny cupules with one nut typically have two valves and dehisce along lines between them ("sutures" in the anatomical sense). In indehiscent fruits with one nut, the valves and sutures are evident at maturity in some species but not others. Fruits with three nuts typically have four valves, dehiscence occurring along the sutures between them (e.g., C. hystrix, Fig. 79; C. schefferiana, Fig. 82), but variations occur in both valve number and location of dehiscence lines. The mature cupule of C. motleyana shown in Figure 9, for example, has three fruits (one apparently abortive), but only two valves are evident. In $C$. tribuloides some cupules are one-flowered and have two valves (Figs. $41,80)$, but other cupules, even on the same rachis, are three-flowered and have four valves (Figs. 42, 43). In the latter, some sutures between valves may not rupture.

Species with one and three nuts per cupule occur at all elevations in southeastern Asia and southwestern Pacific islands, but in Taiwan they are only at middle and higher elevations. The size ranges $(1-6 \mathrm{~cm})$ and averages $(\mathrm{ca} .4 \mathrm{~cm})$ of maximum cupular diameters in all the species are about the same in the two areas, except that in southeastern Asia and southwestern Pacific islands there are two lower-elevation species with very large cupules (to $10 \mathrm{~cm}$ in diameter). Average maximum cupular diameter in the species with one-nut cupules is about that of those with three-nut cupules, again excepting the extremely large cupules of two southeastern Asiatic species, both of which have one nut per cupule.

\section{SPECIES WITH SPINY CUPULES}

In early anthesis the cupule is little developed and is hidden by the bracteoles (Figs. 10, 11, 29, $38,47,55,72-76)$, but the cupular scales quickly 


\section{CASTANOPSIS FOXWORTHYI}
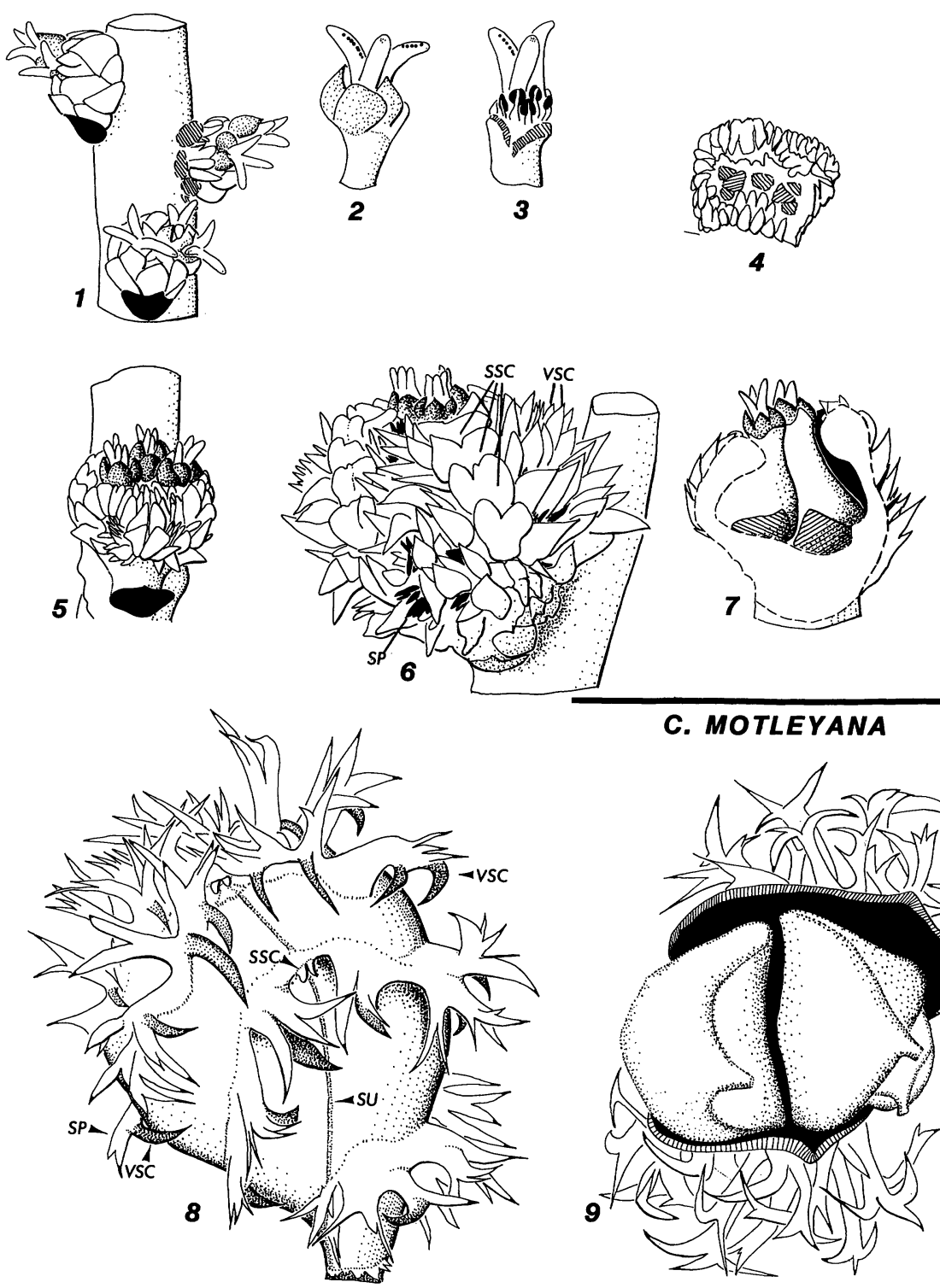

\section{MOTLEYANA}

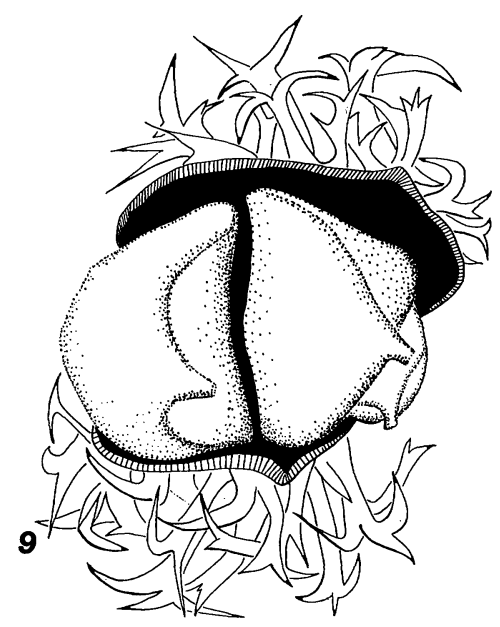

Figures 1-9. 1-8. Castanopsis foxworthyi.-1. Segment of pistillate portion of a spike showing three cymules in anthesis, the primary bract black. Primary bract and the bracteoles are removed in the middle cymule, revealing early cupular scales, $3.8 \times .-2,3$. Flower in anthesis; inferior ovary poorly developed, but staminodia well developed, $7.5 \times .-4$. Polar view of cupule soon after anthesis, revealing scars of seven flowers, the outer four abortive, $3.8 \times .-5$. Cymule after anthesis, with three functional flowers. Cupular scales are differentiating into sutural scales (center) and valvular scales, 3.8×._6. Still later stage, the sutural scales (SSC) and valvular scales (VSC) now clearly differentiated, the axillary spines (black, SP) now showing, 3.8×.-7. Immature cupule longitudinally halved, with two nuts and their basal scar revealed, $3.8 \times .-8$. Nearly mature cupule with the spines now in bands and somewhat confluent. The sutural scales (SSC) have not enlarged as much as the valvular scales (VSC), but the axillary spine clusters (SP) are now mostly much larger than the VSC. The future line of dehiscence between the two valves shown is indicated by SU, 1.9×._. 9. C. motleyana. Mature, dehisced cupule in polar view, revealing one abortive and two functional nuts. The cupule has split on only two of its four sutures, $1.9 \times$. 


\section{CASTANOPSIS MOTLEYANA}
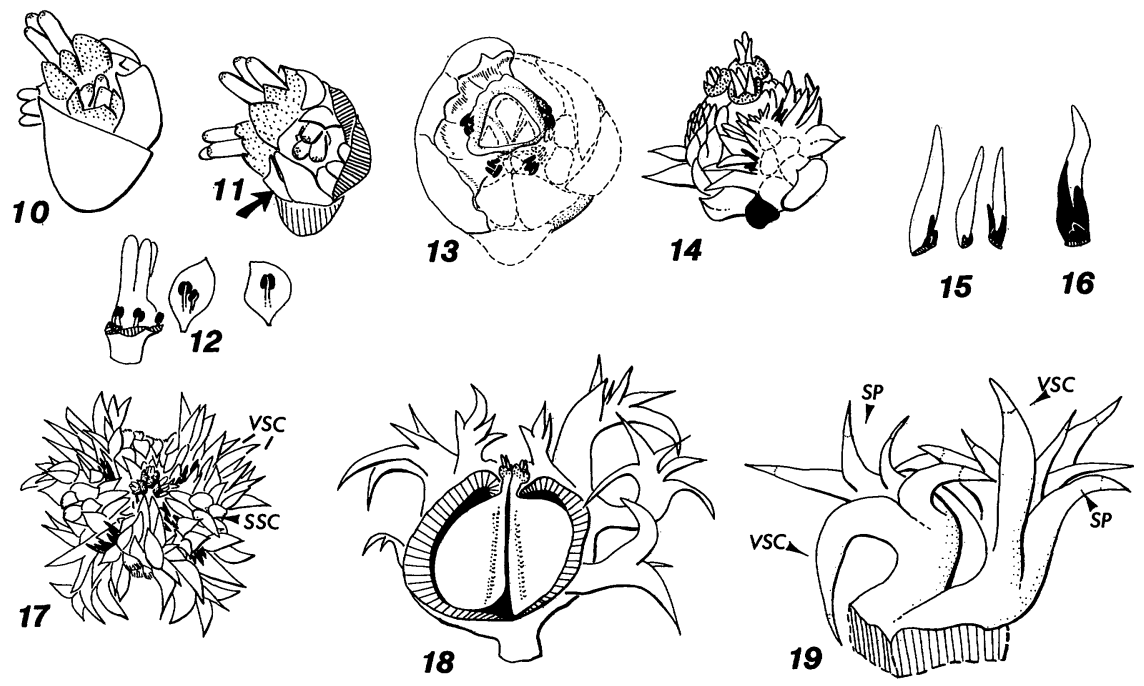

\section{CASTANOPSIS OVIFORMIS}


FIGURES 10-28. 10-19. Castanopsis motleyana.-10, 11. Three-flowered cymule in anthesis, the primary bract and the bracteoles removed in Figure 11 to reveal early cupular scales, the lower two (arrow). being the first sutural scale pairs, $7.5 \times .+12$. A single flower with perianth removed, revealing staminodia basally adnate to the tepals and showing the very undeveloped inferior ovary, $7.5 \times .-13$. Three-flowered cupule in late anthesis, the primary bract (lowermost), the bracteoles on the right half, and some of the early cupular scales removed to reveal the four valvular primordia with their young scales.(black). The second pair of abaxial sutural scales has formed between the lower two valvular primordia, $7.5 \times .+14$. Lateral view of cymule in early postanthesis, the sutural scales (dashed lines) of the right lateral suture removed to reveal the valvular scales and their immature, axillary spines; primary bract black, 3.8×.-15, 16. Valvular scales (white) and early stages of the axillary spines (black), 15×._17. Cupule about one-third mature, the sutural scales (SSC) and valvular scales (VSC) clearly differentiated, and the axillary spines (black) just emerging from among the scales, 7.5×._18. Longitudinally halved immature cupule revealing two of the three nuts, 1.9×._19. Two mature 
become evident and soon exceed the bracteoles (Figs. 5, 14, 25, 30, 39, 40, 52, 56, 77-83). In the species examined for preanthesis developmental detail (Castanopsis foxworthyi, C. motleyana, $C$. oviformis), the cupule primordium arises as an undulate ring at the base of the flowers, well within the bracteoles (Figs. 13, 23). In the threeflowered cymules of $C$. motleyana, four growth centers (valve primordia) of cupular scales are evident in the early stages (Fig. 13, scale primordia shown in black), but growth centers in $C$. foxworthyi and $C$. oviformis are less obvious, although there are differences in development among various parts of the early cupule (Figs. 4, 23, 24).

Distinctions develop among the cupular scales during and after anthesis, especially in cupules that will be spiny at maturity. Columns of shorter, broader, sometimes connate or paired scales alternate with masses of apparently random, pointed scales (Figs. 5, 6, 14, 17, 28, 31-33, 48, 49, $51,58)$. The columns mark the sutures between valves and are potential sites of dehiscence, at which time sutural scales become separated onto adjacent valves (Figs. 34, 41-43, 54). In the threeflowered cupules of Castanopsis foxworthyi, $C$. motleyana, and $C$. inermis there are four such columns: one adaxial, one abaxial, and two lateral (Figs. 6, 13, 51). The columns define the four valves. The first pair of sutural scales is clearly evident in Figure 11, in which the primary bract has been removed to reveal them and the earliest valvular scales. Forman (1966a) found that dehiscence of the cupule of $C$. inermis (Figs. 48-51) does not occur along the sutures between the valves.

The valvular scales between the columns of sutural scales elongate, becoming indurate and spinetipped with age. They do not comprise the majority of spines of the cupule; instead, most of the spines develop later, in groups axillary to the valvular scales; such spines are shown in black in Figures $6,14-17,26-28,31,32,35$, and 36 , and are evident in Figures 72, 77-83. Figures 15 and 16 show that the spines in each group arise nonsynchronously and free, but they become basally connate and ultimately adnate with the subtending scale. By maturity, each subtending scale becomes spine-tipped, and the axillary spines are as large as or larger than it (Figs. 8, 19). Thus, in these spiny-cupuled species, the armament of the cupule is provided mostly by the axillary spines, with some contribution by the original valvular scales (Figs. 8, 37).

In some species with less cupular armament (e.g., Castanopsis tribuloides, Figs. 38-43, 80; C. ferox, Figs. 44-46; C. psilophylla, Figs. 5254 ) the sutural scales are less obviously paired but instead occur in irregular groups. Such groups are evident in Figures 41-44 and 54, which show dehiscence of the cupule through them. In these species, the cupular scales become indurate and spine-tipped, forming much of the cupular armament; the mature axillary valvular spines are of similar size to the scales.

In Castanopsis curtisii (Figs. 55-59, 87) the asymmetric cupule is totally fused to the nut, the surface of which is therefore entirely scarred (Fig. 87) except for a tiny portion near the perianth. The flower and young cupule are rather symmetrical at anthesis (Fig. 55), but asymmetry is established soon thereafter (Fig. 56); massive abaxial growth of the cupule turns the fruit upward about $90^{\circ}$, and it becomes anatropous. Thus at maturity all the sutures appear to be on the adaxial side (Fig. 59). Sutural scales are evident only in the early stages of cupular development, when they can be seen to be entirely adnate to the body of the young cupule (Fig. 56, left cupule). The cupular scales in this species are also largely adnate, and are irregularly disposed at maturity (Fig. 59). In dry fruits, rupturing begins in the adaxial suture, but other ruptures radiate from the cupular pore (Fig. 59); those lines apparently do not represent

spine clusters, each consisting of one spine-tipped valvular scale (VSC) with its axillary cluster of spines (SP), 3.8×. 20-28. C. oviformis.-20. Tip of spike in anthesis. Four one-flowered pistillate cymules are shown in anthesis, the lower with the flower removed to reveal the weakly developed cupule. Unopened distal flowers are staminate, $7.5 \times .-21,22$. Pistillate flower in anthesis, the tepals removed in Figure 22; inferior ovary very undeveloped, but staminodia prominent, $7.5 \times .-23,24$. Cymule in later anthesis, the primary bract and bracteoles removed to reveal the young cupule, $15 \times .-25$. Segment of pistillate portion of spike well after anthesis, the cupule now emergent from the bracteoles; two pairs of large, sutural scales (arrow) are evident on the abaxial side of the uppermost cymule; cymule on lower right removed to reveal persistent bracteole (black), $3.8 \times$. 26. Still older cupule with 12 valvular scales removed to reveal tiny primordia (black) of the axillary spines, $7.5 \times .-27,28$. Immature fruit in lateral (Fig. 27) and abaxial (Fig. 28) view, the axillary spines (black) now appearing among the valvular scales; Figure 28 also shows the abaxial column of large sutural scales, $2.8 \times$. 


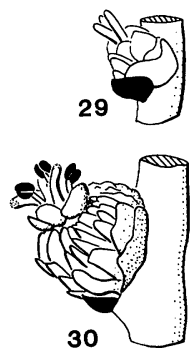

30

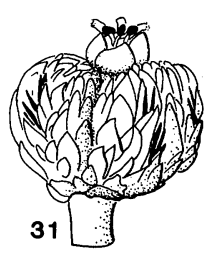

\section{ACUMINATISSIMA}
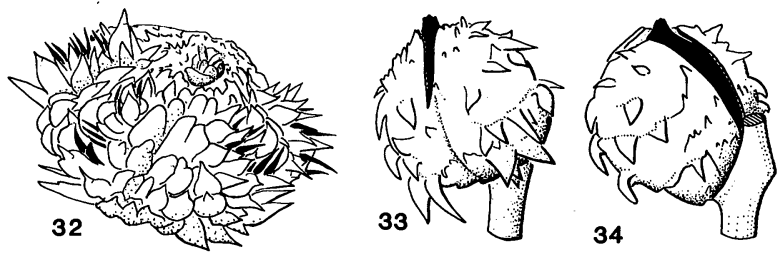

\section{HYPOPHOENICEA}

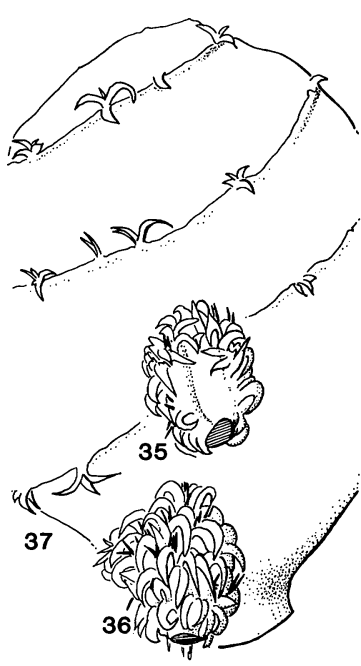

\section{TRIBULOIDES}
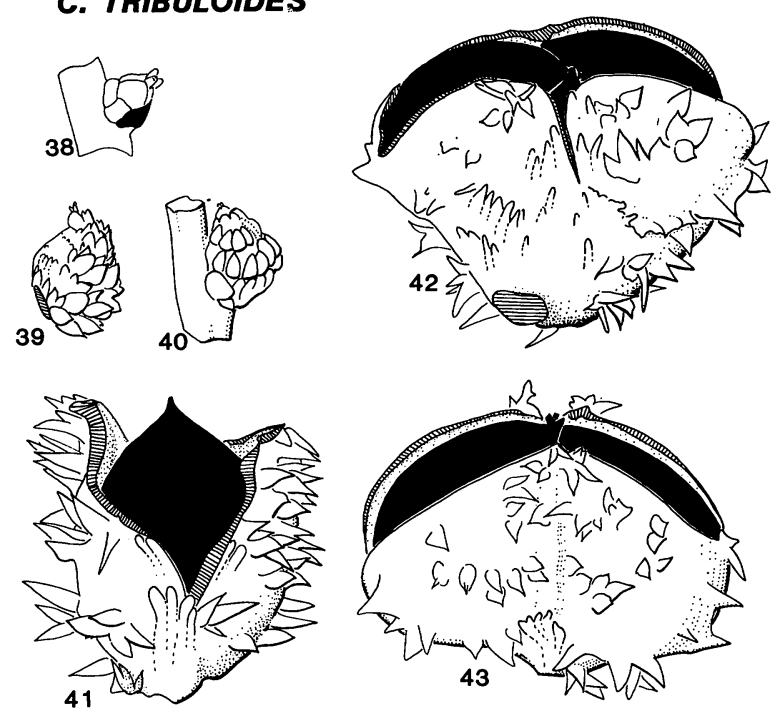

\section{FEROX}


FIGURES 29-46. 29-34. Castanopsis acuminatissima.-29. One-flowered cymule in anthesis, the primary bract in black and a few cupular scales evident, $2 \times .-30$. Late anthesis, the cupular scales evident and overtopping the basal bracteoles; perianth and staminodia obvious, $4 \times .-31$. Still later stage in abaxial view, the axillary spines (black) emerging from among the cupular scales, the abaxial suture indicated by the central, vertical depression abutted by sutural scales, $4 \times .-32$. Still later stage of a specimen showing three sutures defined by appressed scales; between the sutures are groups of axillary spines (black) and valvular scales, $4 \times .-33,34$. Mature, dehiscing cupule showing few spines and dehiscence along two sutures, $2 \times .35-37$. C. hypophoenicea.35. Adaxial view of one-flowered cupule soon after anthesis, the naked adaxial surface distinct, $2 \times .-36$. Abaxial view of the same cupule showing the prominent recurved cupular scales and the emerging axillary spines (black), $2 \times .-37$. Mature cupule, the scales and spines now widely separated and equally spiny, 0.4×. 38-43. C. tribuloides. - 38. One-flowered cymule in early anthesis, the primary bract in black, $2 \times .-39,40$. Somewhat after anthesis, the relatively unadorned adaxial side evident in Figure 39, the neat rows of scales obvious in Figure 40, 2×.-41. Mature, dehiscing cupule in abaxial view, the rounded sutural scales evident adjacent to the suture, but the rows of valvular scales are no longer orderly, $2 \times .-42$, 43. Adaxial (Fig. 42) and abaxial (Fig. 43) views of dehiscing cupule containing three nuts. Rounded scales of the partially opened adaxial 
intervalvular sutures, or at least such sutures are not evident in earlier stages (Figs. 57, 58). These fruits are possibly indehiscent in the wild, where they perhaps never dry, but my dry specimens show regular patterns of splitting.

Four related species reveal comparative details of reproductive structure: Castanopsis armata, $C$. inermis, C. lucida, and $C$. pierrei. The cupule is almost entirely fused to the nut in $C$. pierrei (Figs. $65,86)$. Figure 65 shows the massive scar (hatched) and two small abortive nuts near the distal end of the single mature nut. The small free portion of each nut is indicated in black. The relationship of the mature and immature nuts to the cupule is evident in Figure 86, a polar view wherein the partially open cupule reveals two abortive nuts on the right. In this species the cupular scale-spine complexes are massively thickened (Figs. 65, 86). The spine-tips are not much elongated, but they are very sharp. The scale-spine complexes are arranged in slanting rows on the cupule, but that is not evident in Figures 65 and 86.

Castanopsis armata is similar to $C$. pierrei in that the cupule is entirely fused to the nut, but my specimens have no abortive nuts, and the single mature nut has about $20 \%$ of its distal end free (nonscarred) (Fig. 88). The mature cupule is massively thickened, and the cupule scale-spine complexes are not aligned in evident rows at maturity but are even more massive than those of $C$. pierrei. Each spine has a short, indurate, subulate tip, and the cupule is therefore formidably armed. Immature fruits display cupular sutures (cf. Fig. 51), along which dehiscence probably occurs eventually.

In Castanopsis inermis the cupule contains one to three nuts and is largely free from them (Fig. 89). Forman (1966a) noted a tendency toward reduction of the central flower of each cupule in this species, but I cannot confirm or deny that from observations of specimens from the Malay Peninsula, which show no regular pattern of reduction. The mature cupule displays horizontal rows of groups of low spines (Fig. 89, center). Such regular arrangement is more obvious on immature cupules, where the sutural scales are also readily distinguished (Figs. 48-51). The latter are permanently adnate to the cupule and do not become spiny. The cupular armament is largely made of spinetipped cupular scales; axillary spines, if present, contribute little. Usually four sutures form on threeflowered cupules, and two form on one-flowered cupules. Variation occurs; some one-flowered cupules have four sutures (Fig. 51), for example. Dehiscence does not follow the sutures entirely and is therefore rather irregular.

The large fruits of Castanopsis lucida (Fig. 85) resemble those of $C$. inermis, but the cupular scale groups are proportionally larger and, at least in my specimens, the cupules seldom contain fewer than three nuts. The four sutures of a three-nut cupule are clearly evident in Figure 85 (upper photograph). Dehiscence usually begins with the opening of the adaxial and abaxial sutures, which are the shorter ones; later the longer lateral sutures open and reveal the free nuts within (Fig. 85). Mature spikes sometimes bear as many as ten fruits that collectively weigh $70 \mathrm{~g}$ when dry.

\section{SPECIES WITH SMOOTH CUPULES}

Some species of Castanopsis have nearly smooth, figlike cupules. Examples are shown of $C$. piriformis, C. guineri, and C. longipetiolata (Figs. 6064, 66-69, 84, 89-91), all placed in section Callaeocarpus by Camus (1929). In these the indehiscent cupule is fused to the single nut and is unadorned except for low ridges and small, mostly adnate scales. No axillary spine complexes form.

The cupular scale-bearing ridges are widely separated and not concentric. In Castanopsis piriformis and $C$. guineri they converge distally on the cupule and there form a continuous spiral around the aperture (Figs. 62, 63, 84, 90). The ridges of C. longipetiolata are vertical in places (Figs. 67$69,91)$ and converge near the aperture, but do not form a spiral (Fig. 67).

In adaxial view (Figs. 61, 64, 68), the adaxial suture is barely evidenced by a broad longitudinal depression. A few sutural scales show in Figures 61 and 64, but there are none in Figure 68. The cupular scales enlarge little as the cupule swells, and thus they become somewhat remote. In Cas-

suture are seen to intergrade with the pointed valvular scales in Figure 42, but sutural scales on the abaxial side are confined to the base of the cupule (Fig. 43), 2×.-44-46. C. ferox showing mature, dehiscing cupule in abaxial, lateral, and adaxial views, respectively. The adaxial side is essentially naked, and the suture there is without adjacent scales; the abaxial suture (Fig. 44) has a few scales, and the valvular scales are irregularly disposed at maturity, $2 \times$. 


\section{INERMIS}


\section{PSILOPHYLLA}
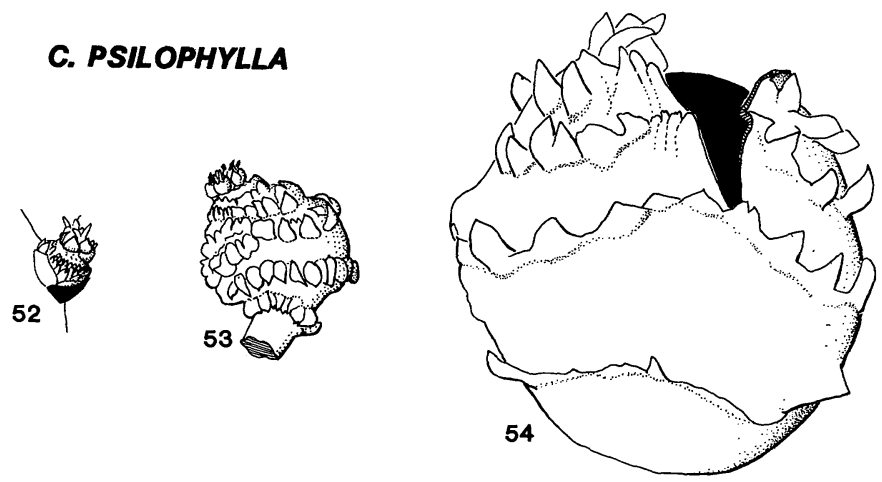

\section{CURTISII}
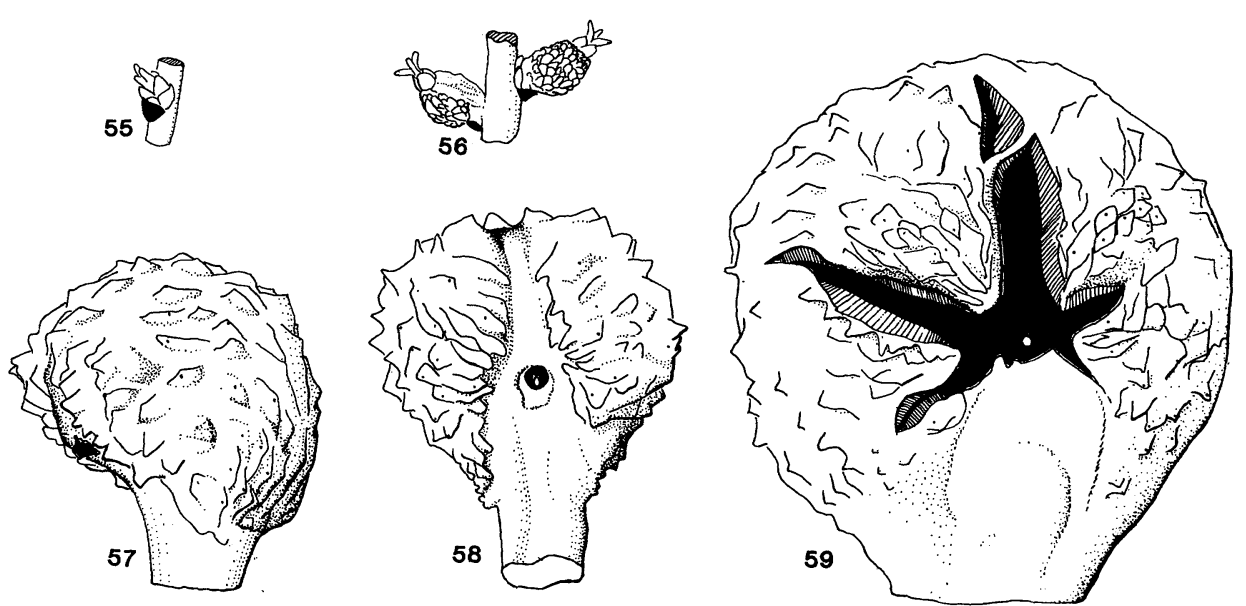

FiguREs 47-59. 47-51. Castanopsis inermis.-47. Three-flowered cymule in early anthesis, the primary bract shown in black, and only two cupular, scales visible between the basal bracteoles, $2 \times$. - 48. Immature cupule in lateral view, the abaxial suture on the left shaded, the valvular scales still in rows, $2 \times .-49$. Nearly mature cupule in adaxial view, the rounded sutural scales of the adaxial suture in tiers, the valvular scales less orderly than in Figure 48, 2×.-50. Lateral view of nearly mature cupule, showing rows of valvular scales, $2 \times .-51$. Oblique polar view of nearly mature cupule, the four sutural areas evident and defined by appressed, more or less rounded sutural scales, and the valvular scales fully enlarged and pointed; there are no evident axillary spines, 2×. 52-54. C. psilophylla.-52. Three-flowered cymule in anthesis, the primary bract in black and the large basal bracteoles in white; numerous cupular scales are evident in rows above the bracteoles, $2 \times .-53$. Postanthesis, the cupule and its scales enlarging, the latter yet in evident rows; perianths and staminodia of the three flowers persisting, 2×.-54. Mature, dehiscing cupule in abaxial view, showing a few elongate, appressed sutural scales to the left of the suture; valvular scales yet in rows but somewhat separated by diametric growth of the cupule, $2 \times$. 55-59. C. curtisii.-55. One-flowered cupule in early anthesis, the primary bract shown in black, the cupular scales present under the basal bracteoles but not evident in this figure, $2 \times .-56$. Two cymules soon after anthesis, the cupule already prominent above the primary bract and basal bracteoles, 


\section{PIRIFORMIS}
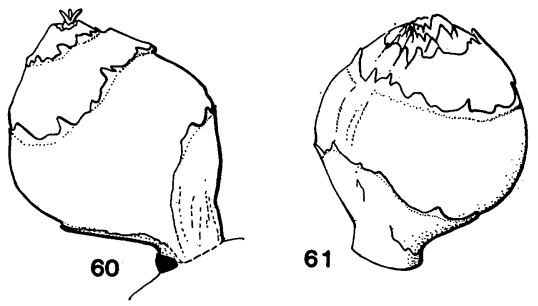

\section{GUINERII}
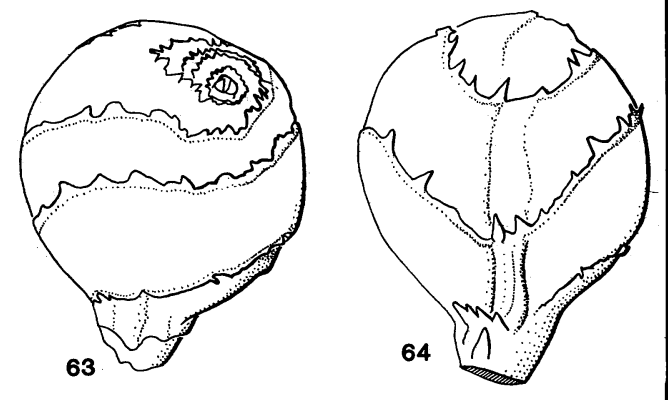

62

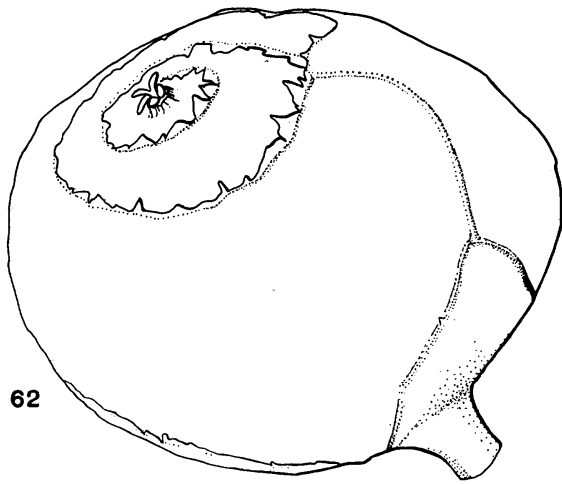

\section{PIERRE}
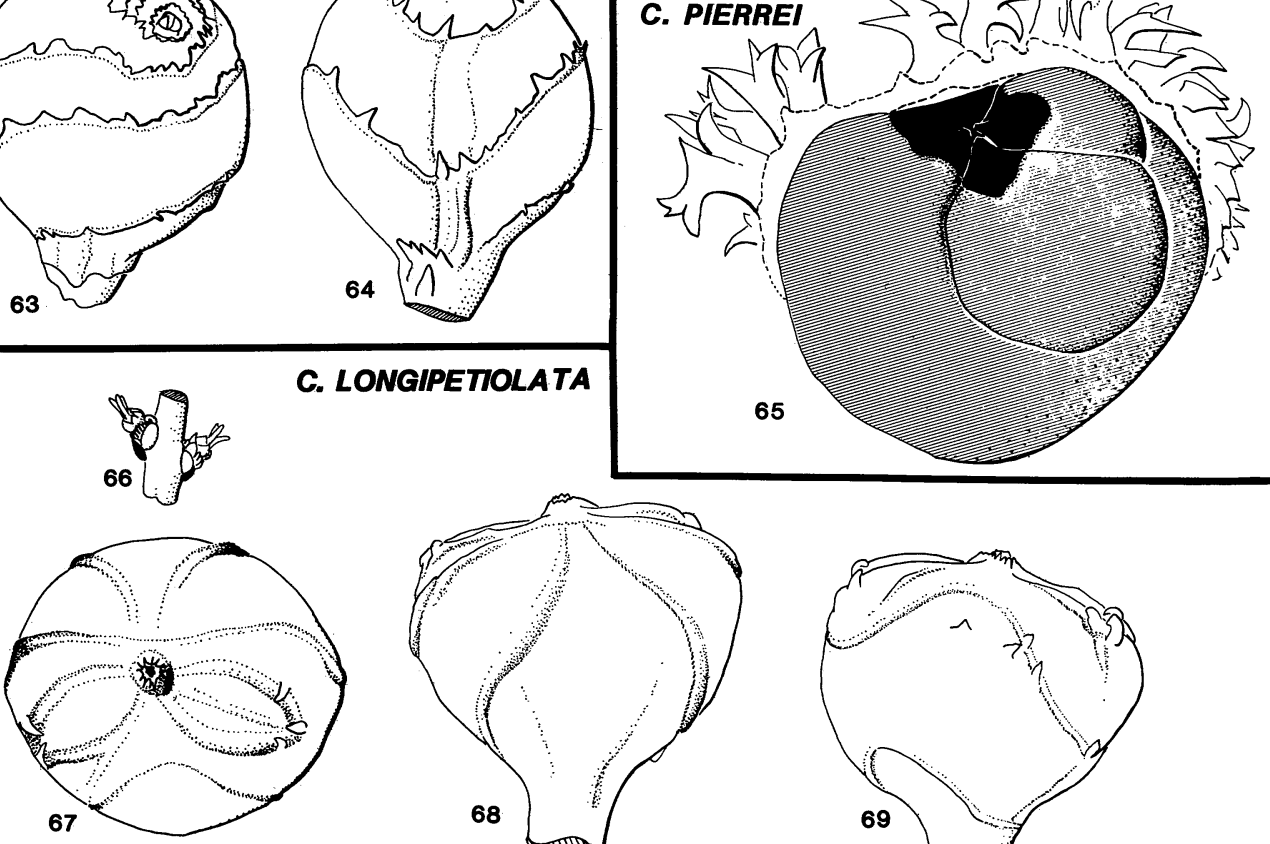

C. LONGIPETIOLATA
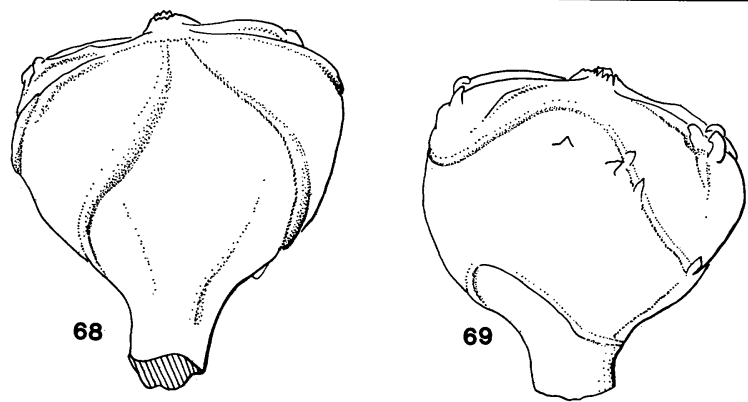

FigURES 60-69. 60-62. Castanopsis piriformis.-60, 61. Half-mature one-flowered cupule in abaxial (Fig. 60) and semiadaxial (Fig. 61) views. The primary bract is shown in black in Figure 60. Cupular scales are already torn and widely spaced by this stage. The potential adaxial suture is seen on the left in Figure 61, although the fruit is probably indehiscent, $2 \times .-62$. Mature cupule in oblique view, the adaxial side to the right. Upper rows of scales becoming spiral, $2 \times .-63,64$. C. guineri, nearly mature fruits in abaxial (Fig.63) and adaxial (Fig. 64) views. The strong spiral formation of cupular ridges is evident in Figure 63, and Figure 64 shows the adaxial vertical depression marking a potential suture, although the fruit is indehiscent, $2 \times .-$ 65. C. pierrei. Mature fruit with foreground part of cupule removed to expose the massive scars (white) of the three nuts, two of which developed only partially; free portion of the nuts shown in black. The nuts are not fused to each other, 2×. 66-69. C. longipetiolata.-66. Two one-flowered cupules in anthesis, the primary bract of each shown in black; the first row of cupular scales is apparent above the basal bracteoles, 2×.-67-69. Nearly mature cupule in polar, adaxial, and lateral views, respectively. The few surviving cupular scales are mostly adjacent to the curving cupular ridges, and there is no obvious indication of potential sutures on this indehiscent cupule, $2 \times$.

$\leftarrow$ the scales more or less in orderly rows; the rather smooth, unadorned adaxial face of the left cupule is easily seen, 2×.-57, 58. Fruit about half grown, in lateral (Fig. 57) and adaxial (Fig. 58) views. Massive adaxial growth has produced strong asymmetry, and the pore through which the tip of the nut can be seen is now more than $90^{\circ}$ from the vertical. Scales are no longer in rows, and some slight differentiation is beginning directly to the right and left of the pore, $2 \times .-59$. Mature dehiscing cupule in adaxial view. Five lines of dehiscence are shown on this specimen, the vertical one through the upper, unadorned area visible in Figure 58 and the two upper, lateral ones between the barely differentiated scales, $2 \times$. 

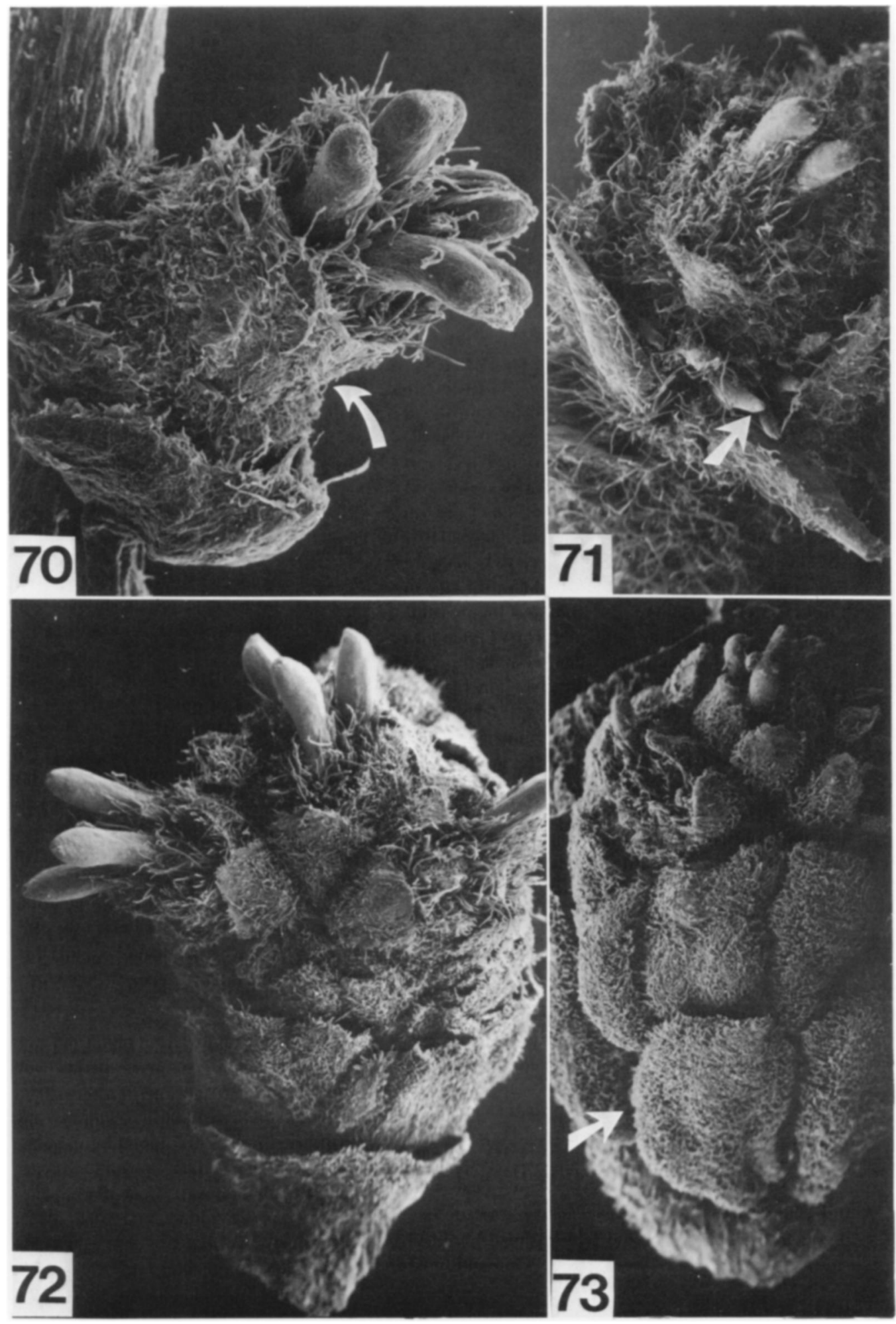

Figures 70-73. 70. Castanopsis tribuloides, lateral view of cymule in anthesis. The large primary bract is lowermost, but no cupular scales show between it and the prominent perianth (arrow), $65 \times .-71$. C. indica, 
tanopsis longipetiolata there are few such scales from the beginning, so by maturity the cupule is nearly scaleless (Figs. 67-69, 91). No axillary spine complexes form.

\section{DISCUSSION}

Castanopsis shows primitive and advanced character states for the Fagaceae. If multiflowered cymules are primitive in the family, as suggested by Soepadmo (1970, 1972), Forman (1966a), and Kaul (1987), and by widely accepted interpretations of inflorescence evolution in the angiosperms, then it is likely that some associated character states are primitive too. Among the latter possibilities are four-valved cupules, dehiscence between the valves, the cupule free from the nut(s), and spines present on the cupule (Forman, 1966a). The general association of one-flowered cupules with spinelessness, adnation of the cupule to the nut, and irregular or no dehiscence thus suggests those states to be advanced. Forman (1966a) postulated such interpretations based upon other species, and they are supported by my observations. If the interpretations of Hjelmqvist (1948) and Forman (1966a) are correct, the dichasium cupule evolved by phylogenetic fusion of adjacent flower-cupules in the cymule and is thus highly derived. Strong cupular asymmetry approaching anatropy, as in $C$. curtisii, is certainly a derived state, although most species show at least some asymmetry.

There is some developmental evidence that adnation of cupule to nut is only apparent. Rather, it is possible that the basal scar enlarges enormously as the nut grows in species with apparently extensive adnation and that the basal part of the cupule expands simultaneously. The result is wide spacing of the lower cupular lamellae, but distally they remain rather crowded. With this interpretation the figlike, one-nut cupules can be viewed as the products of massive basal but little distal enlargement of the cupule. The distal part of the nut, which in other species enlarges more than the basal part, remains free, as it is in the species without apparent cupular adnation. Detailed developmental investigations, though technologically formidable, could provide further insights into this idea.
In some species, the scales and spines are arranged in concentric rows, but in others there is no apparent order in mature cupules. However, in the latter instances observed for this study, early developmental stages show rather regular rows of cupular scales, and I regard such rows as the primitive condition in the genus. In some species with figlike cupules (e.g., Castanopsis guineri, C. piriformis) the parallel rows of scales on the lower part of the mature cupule contrast with the distal, spiral rows, which are the last to form. The cupules of some species of Quercus subg. Cyclobalanopsis also show spiral lamellations, but most species of that subgenus, all of subg. Quercus, and nearly all of Lithocarpus have concentric lamellae (Kaul, 1985,1987 , and in press). Thus spiral lamellations are exceptional in the Fagaceae and are likely to have been derived by modification of the concentric pattern through alteration of later ontogenetic stages.

Forman (1966a) interpreted the sutural scales as derived from branched spines because he believed there are intermediates between scales and spines in some species. He thus considered the cupular scales of Lithocarpus and Quercus also to be modified spines. He saw the spines as single branched entities, but Barnett (1940) interpreted them as axillary to the first-formed cupular appendages. I also interpret the sutural and valvular scales to be homologous and synchronous, and the axillary spines to arise above the valvular but not the sutural scales. Thus intermediates between the two scale types are expected and, in fact, have been observed by Forman (1966a) as well.

Plant spines are sometimes emergences, not stem or leaf homologues, and that was Forman's (1966a) interpretation of the cupular appendages of $\mathrm{Cas}$ tanopsis. Evidence in favor of the spines of Castanopsis being modified stems are their branching capability (which sometimes occurs in other families in spines originating as emergences) and their position axillary to the scales. However, there are not even ephemeral subtending bracts at the nodes of branching on the spines, as could be expected in a reduced branching system. Furthermore, it is possible that the scales and spines, as defined here, are homologues and therefore not fundamentally different as suggested by the scale/axillary spine

polar view of cymule soon after anthesis, five spines (arrow) appearing through the bracteoles and hairs, $28 \times .-72$. C. pierrei, abaxial view of three-flowered cymule in anthesis. A few cupular scales (arrow) are evident above the large basal bracteoles and below the perianths, $29 \times .+73$. C. schefferiana, abaxial view of cymule soon after anthesis, the styles still showing. The cupular scales are now prominent above the basal bracteoles, $27 \times$. 


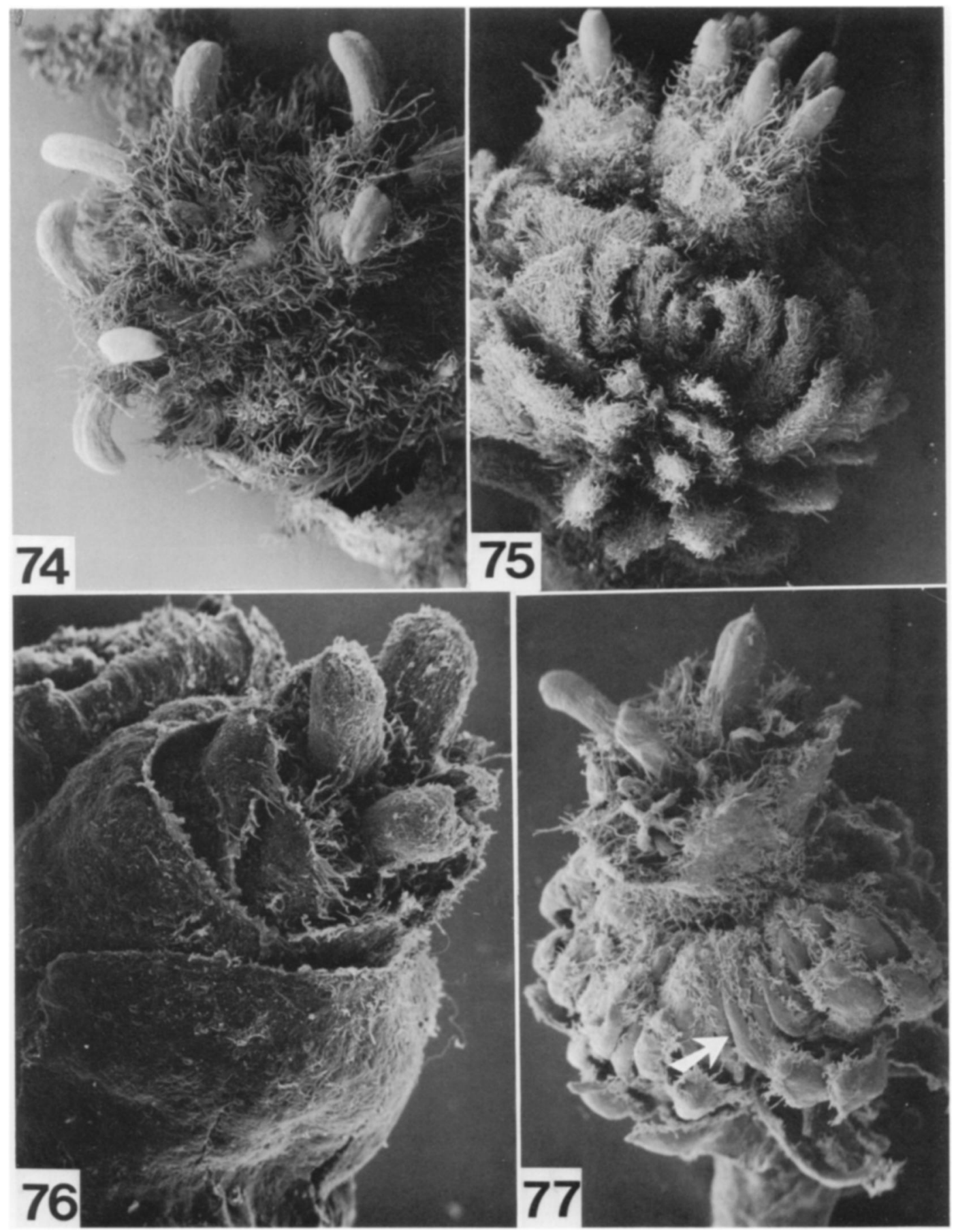

FIGURES 74-77. 74, 75. Castanopsis foxworthyi.-74. Abaxial view of three-flowered cymule in late anthesis. The subtending primary bract is seen in the lower right corner, but the bracteoles, emerging cupular scales, and much of the perianths are obscured by hairs, 32×.-75. Semiabaxial view of a cymule not long after anthesis, the abundant cupular scales having emerged from beneath the basal bracteoles. A few of the subulate structures are probably emerging spines, $24 \times .76,77$. C. acuminatissima.- 76 . One-flowered cymule at anthesis, in nearly abaxial view. The prominent primary bract is below, and the equally large subtending bracteoles are just above it; only the perianth and styles emerge at this stage, 29x.- 77. Cymule not long after anthesis, in nearly abaxial view. The subtending primary bract below is barely in focus, but the numerous cupular scales are plainly seen, as are a few emerging subulate spines (arrow), which are yet appressed to the young cupule. Some shriveled staminodia are seen below the styles, $24 \times$. 

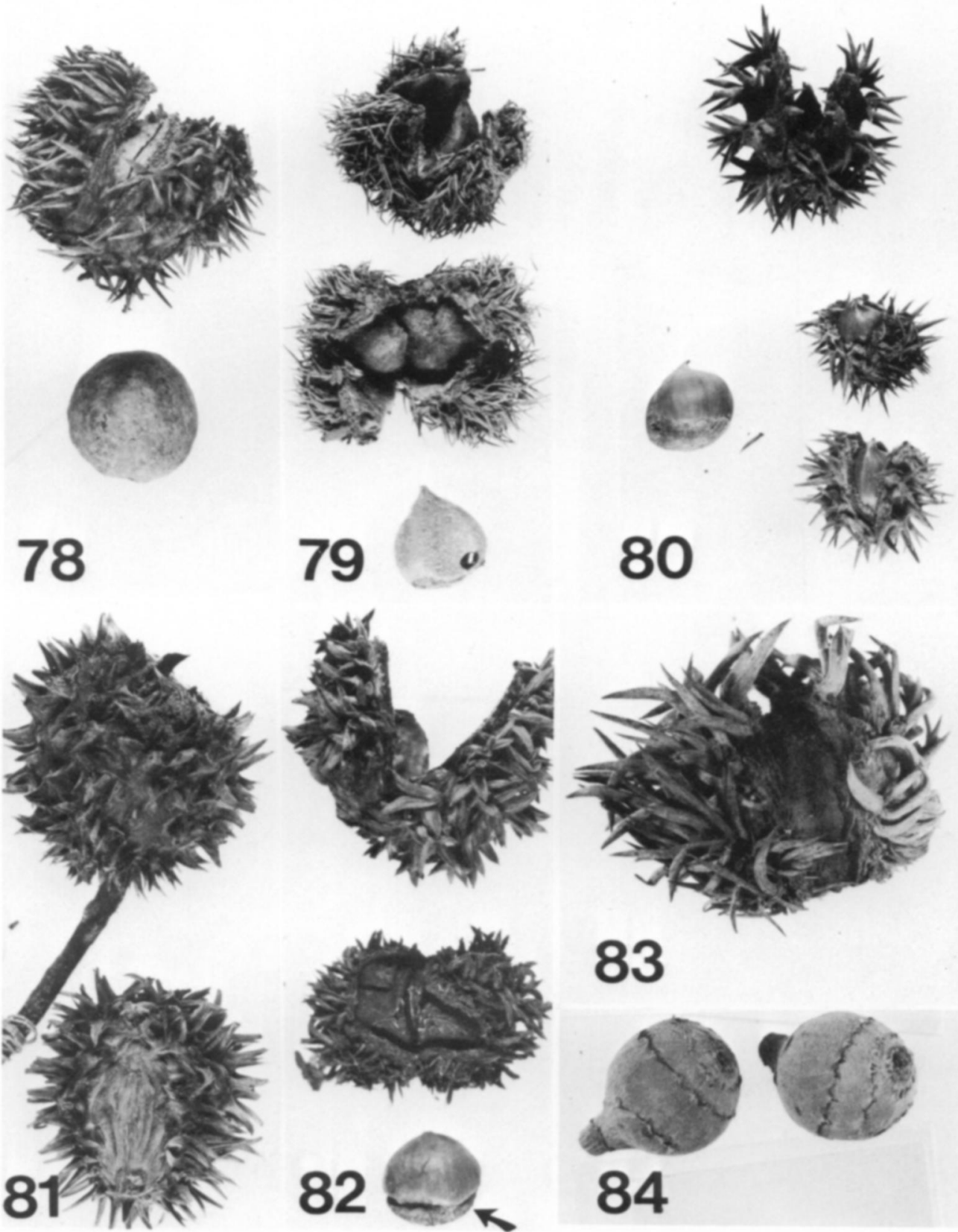

\section{0}
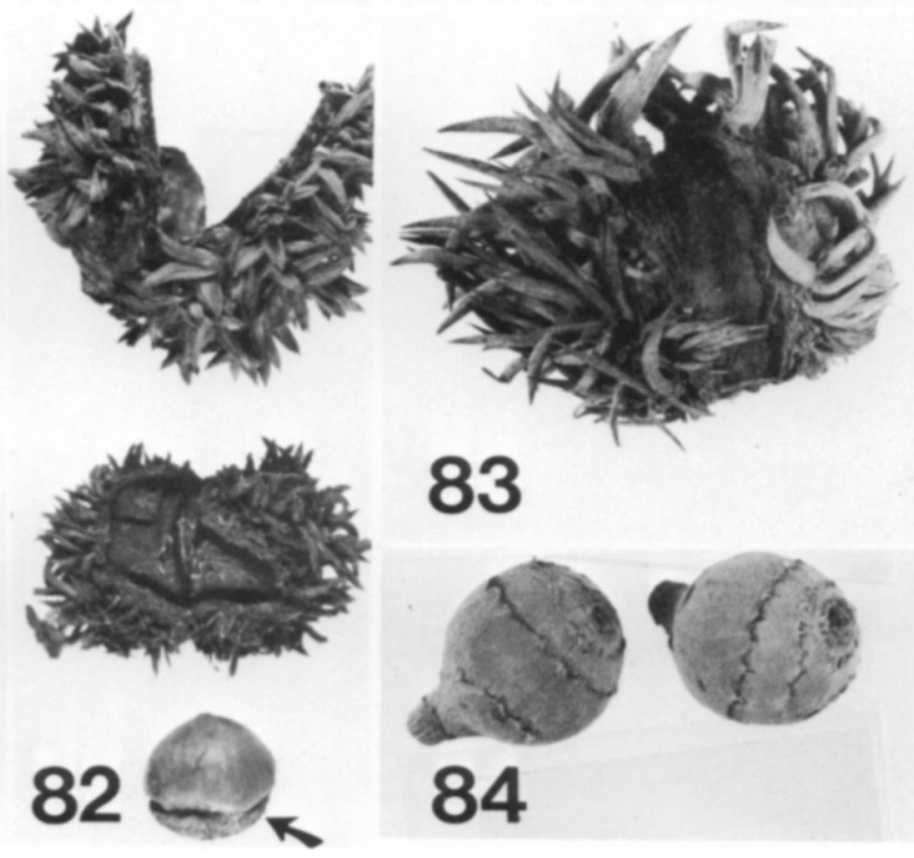

FIGURES 78-84. Mature fruits of Castanopsis.-78. C. argophylla. Cupule dehiscing on two sutures, the nut free from it, 1.6×.-79. C. hystrix. Three-nut cupules dehiscing on four sutures, the nuts free, $0.8 \times .-80$. C. tribuloides. One-nut cupules dehiscing on two sutures, the nut free, 1.2×.-81. C. formosana. Abaxial and adaxial views (upper and lower cupules, respectively). The unadorned adaxial surface is seen in the lower cupule, $1 \times$.82. C. schefferiana. Lateral and polar views (upper and central figures) of a three-nut cupule dehiscing on four sutures; the basal scar (arrow) of a nut shows in the lowest figure, 1.2×.-83. C. purpurea. Mature cupule armed with heavy, curved spines; the unadorned suture is evident in the center, $1.3 \times .-84$. C. guineri. Mature, slightly asymmetric cupule in lateral views, showing the lamellae with the few persisting scales, $1 \times$ (cf. Figs. $63,64)$. 

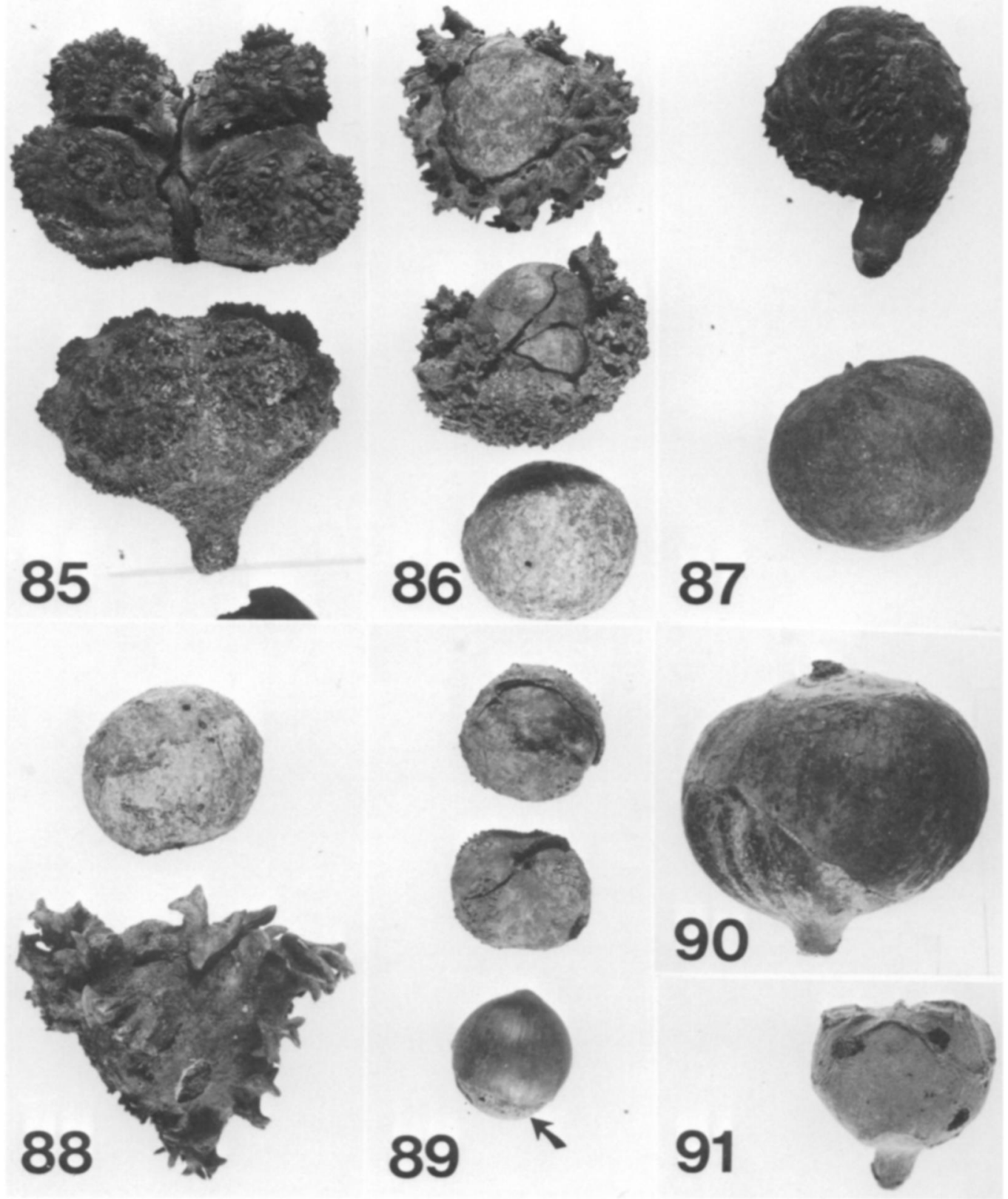

FigURES 85-91. Mature fruits of Castanopsis. - 85. C. lucida. Mature, dehiscing cupule in polar (upper) and abaxial (lower) views. This specimen has three nuts free from the cupule, the central one apparently abortive (upper figure), $1 \times .-86$. C. pierrei. Mature fruit in lateral (upper figure) and polar (central figure) views. In the central figure, two abortive nuts are revealed to the right of the large, fertile nut (cf. Fig. 65). The fertile nut is shown removed from the cupule in the lowest figure; only the dark, upper part was free from the cupule, $0.8 \times .-87$. C. curtisii. Upper figure: mature cupule in nearly adaxial view, the entire fruit anatropous, the apical pore visible left-central. Lower figure: mature nut removed from cupule and viewed laterally. The scar covers nearly the entire surface, $1 \times .-88$. C. armata. Mature nut (upper figure) entirely scarred from fusion to the cupule, and lateral view (lower figure) of mature cupule with its massive but sparse armament, 1.3×.-89. C. inermis. More or less polar views (upper two figures) of mature cupule dehiscing along two sutures and showing only weak definition of sutural (unadorned) and valvular areas (cf. Figs. 47-51). Lowest figure is the mature nut, its basal scar (arrow) clearly evident, 1×.—90. C. piriformis. Lateral view of mature cupule (entirely fused 
interpretation. For Castanea, Fey \& Endress (1983) interpreted the valvular scales to be residual pherophylls of a condensed, cymose system and the spines to be axillary, cymose branches, based upon their comparative and developmental studies. I favor that interpretation for Castanopsis as well.

If the branched spines are relictual axillary branches - vestiges of a condensed, fused branching system that formed the cupule-then their presence is the primitive condition in the family. Their loss, both within Castanopsis and elsewhere in the family, would be the derived state. Spininess due to induration of cupular scales in a few species of Quercus and Lithocarpus would then be a secondary development.

Whatever interpretation is correct, there are unanswered questions about evolution of the various patterns of spine elaboration and distribution on the cupules. While protection of the immature nuts is a likely function of the spines, the fact that some nonspiniferous species of Castanopsis grow in the same forests with spiniferous species suggests that other protective measures are effective too. Detailed studies of life histories of Castanopsis and of its fruit predators and disseminators could reveal important information about cupular function.

It is likely that the solitary pistillate flowers of some species of Lithocarpus and Castanopsis and all species of Quercus are the results of phylogenetic elimination of all flowers but one (presumably the terminal one) of a cymule, as suggested by Forman (1966a). However, it is by no means evident that abortive flowers are always phylogenetically abortive - sometimes they are merely normal flowers that failed to produce fruit, probably for lack of pollination or fertilization, or due to competition from other fruits on the same rachis. Such failed flowers are frequent even among species with solitary flowers. In this paper and elsewhere (Kaul, 1987 and in press) examples are illustrated showing failed flowers of multiflowered cymules in every position in the cymules, varying greatly even on a single spike. If there are tendencies for lateral flowers in pistillate cymules of these genera to be phylogenetically abortive, I have seen little convincing evidence. However, such evidence appears in a few staminate spikes of Lithocarpus and possibly also of Castanopsis.
There are more differences in cupular structure within Castanopsis than between it and some species of Lithocarpus, and the distinctions between flower-cupules of the latter and dichasium-cupules of the former are not always convincing, especially in Lithocarpus species with cupules partially of both types. Thus, once again the generic and infrageneric taxonomy of Fagaceae is questioned: the long history of taxonomic doubt expressed in the literature is not eased by such observations. However, it is premature to propose new alignments because of the confusing levels of apparent parallelism and convergence in these large genera.

\section{Literature Cited}

ABBE, E. C. 1974. Flowers and inflorescences of the "Amentiferae." Bot. Rev. 40: 159-261.

BarnetT, E. C. 1940. A Survey of the Genus Quercus and Related Genera of the Fagaceae in Asia, with a More Detailed Account of the Siamese Species of These Genera. D.Sc. Thesis. University of Aberdeen (unpubl.).

- 1942. The Fagaceae of Thailand and their geographical distribution. Trans. Bot. Soc. Edinburgh 33: $327-343$.

1944. Keys to the species groups of Quercus, Lithocarpus, and Castanopsis of eastern Asia, with notes on their distribution. Trans. Bot. Soc. Edinburgh 34: 159-204.

Camus, A. 1929. Les châtaigniers. Monographie des genres Castanea et Castanopsis. Encycl. Ëcon. Sylvic. 3: 1-604.

Crepet, W. L. \& C. P. Daghlian. 1980. Castaneoid inflorescences from the Middle Eocene of Tennessee and the diagnostic value of pollen (at the subfamily level) in the Fagaceae. Amer. J. Bot. 67: 739-757.

Erdtman, G. 1943. An Introduction to Pollen Analysis. Ronald Press, New York.

FEy, B. S. \& P. K. EndRess. 1983. Development and morphological interpretation of the cupule in Fagaceae. Flora 173: 451-469.

Forman, L. L. 1966a. On the evolution of cupules in the Fagaceae. Kew Bull. 18: 385-419.

- 1966b. Generic delimitation in the Castaneoideae. Kew Bull. 18: 421-426.

HJELmQvist, H. 1948. Studies on the floral morphology and phylogeny of the Amentiferae. Bot. Not. Suppl. 2: $1-171$.

- 1968. Studies in the flora of Thailand 44: Fagaceae, Betulaceae and Corylaceae. Dansk Bot. Ark. 23: 473-516.

JoNES, J. H. 1986. Evolution of the Fagaceae: the implications of foliar features. Ann. Missouri Bot. Gard. 73: 228-275.

to the nut), the weakly defined, remote lamellae essentially without scales; the distal lamellar spiral is seen more clearly in Figure 62, 1×.-91. C. longipetiolata. Mature cupule in lateral view (entirely fused to the nut) showing the few naked lamellar ridges. The three dark spots are areas apparently damaged by chewing animals, $1.2 \times$. 
KaUl, R. B. 1985. Reproductive morphology of Quercus. Amer. J. Bot. 72: 1962-1977.

1986. Evolution and reproductive biology of inflorescences in Lithocarpus, Castanopsis; and Quercus (Fagaceae). Ann. Missouri Bot. Gard. 73: 284-296.

- 1987. Reproductive structure of Lithocarpus sensu lato (Fagaceae): cymules and fruits. J. Arnold Arbor. 68: 73-104.

- Fruit structure and ecology in paleotropical Lithocarpus. In: S. Blackmore \& P. Crane (editors) Evolution, Systematics and Fossil History of the Hamamelidae. Oxford Univ. Press, Oxford, England. (In press.)

\& E. C. ABBE. 1984. Inflorescence architecture and evolution in the Fagaceae. J. Arnold Arbor. 65: 375-401.

LI, H.-L. 1963. Woody Flora of Taiwan. Livingston Publ. Co., Narberth, Pennsylvania.

LiAO, J.-C. 1971. Morphological studies on the flowers and fruits of the genera Fagus, Castanea, Casta nopsis and Limlia in Taiwan. Mem. Coll. Agric. Natl. Taiwan Univ. 12: 83-113.

LiN, W.-F. \& T.-S. Liu. 1965. Studies on the classification of Fagaceae in Taiwan. Bull. Taiwan Forest Res. Inst. 110: 1-59.

LiU, T.-S. \& J.-C. LiaO. 1976. Fagaceae. In: H.-L. Li et al. (editors), Flora of Taiwan 2: 49-104.
OHwI, J. 1965. Flora of Japan. Smithsonian Institution, Washington. [English translation.]

Окамото, M. 1982. A consideration on the cupules of the Fagaceae. Acta Phytotax. Geobot. 33: 321-327. 1983. Floral development of Castanopsis cus pidata var. sieboldii. Acta Phytotax. Geobot. 34: 10-17.

Paijmans, K. 1976. New Guinea Vegetation. Elsevier North-Holland, New York.

SoEPADMO, E. 1968. Florae Malesianae praecursores XLVII. Census of Malesian Castanopsis (Fagaceae). Reinwardtia 7: 383-410. 1970. Florae Malesianae praecursores XIIX. Malesian species of Lithocarpus Bl. (Fagaceae). Reinwardtia 8: 197-308. - 1972. Fagaceae. Flora Malesiana I. 7(2): $265-403$

W ANG, C.-W. 1961. The Forests of China. Maria Moors Cabot Found. Publ. No. 5. Harvard Univ., Cambridge, Massachusetts.

Whitmore, T. C. 1975. Tropical Rain Forests of the Far East. Clarendon Press, Oxford.

Zavada, M. S. \& D. L. Dilcher. 1986. Comparative pollen morphology and its relationship to phylogeny of pollen in the Hamamelidae. Ann. Missouri Bot. Gard. 73: 348-381. 